Vol. 5 (1996): 367-376.

\title{
Monitoring and predicting crop growth and analysing agricultural ecosystems by remote sensing
}

\author{
Tsuyoshi Akiyama' and Y. Inoue \\ M. Shibayama \\ National Grassland Research Institute, Japan \\ Y. Awaya and N. Tanaka \\ Forestry and Forest Products Research Institute, Japan
}

National Institute of Agro-Environmental Sciences, 3-1-1, Kannondai, Tsukuba, Ibaraki 305, Japan

\begin{abstract}
LANDSAT/TM data, which are characterized by high spectral/spatial resolutions, are able to contribute to practical agricultural management. In the first part of the paper, the authors review some recent applications of satellite remote sensing in agriculture. Techniques for crop discrimination and mapping have made such rapid progress that we can classify crop types with more than $80 \%$ accuracy. The estimation of crop biomass using satellite data, including leaf area, dry and fresh weights, and the prediction of grain yield, has been attempted using various spectral vegetation indices. Plant stresses caused by nutrient deficiency and water deficit have also been analysed successfully. Such information may be useful for farm management. In the latter half of the paper, we introduce the Arctic Science Project, which was carried out under the Science and Technology Agency of Japan collaborating with Finnish scientists. In this project, monitoring of the boreal forest was carried out using LANDSAT data. Changes in the phenology of subarctic ground vegetation, based on spectral properties, were measured by a boom-mounted, four-band spectroradiometer. The turning point dates of the seasonal near-infrared (NIR) and red (R) reflectance factors might indicate the end of growth and the beginning of autumnal tints, respectively.
\end{abstract}

Key words: arctic area, biomass, environment, phenology, spectroradiometer, vegetation, yield

'Current address: Institute for Basin Ecosystem Studies, Gifu University, Yanagido, Gifu 501-11, Japan,e-mail: akiyama@green.gifu-u.ac.jp 
Akiyama, T. et.al.: Analysing agricultural ecosystems by remote sensing

Table 1. Characteristics of earth observing satellites.

\begin{tabular}{|c|c|c|c|c|}
\hline $\begin{array}{l}\text { Satellite/ } \\
\text { sensor }\end{array}$ & $\begin{array}{l}\text { Launched/ } \\
\text { yr/revolution }\end{array}$ & $\begin{array}{l}\text { Wavelength } \\
\text { range } \mathrm{nm}\end{array}$ & Band & $\begin{array}{l}\text { Ground } \\
\text { resolution }\end{array}$ \\
\hline NOAA/ & U.S.A & C1: $580-680$ & Visible & $1.1 \mathrm{~km}$ \\
\hline \multirow[t]{3}{*}{ AVHRR } & (1978-) & $\mathrm{C} 2: 725-1100$ & Near-IR & $1.1 \mathrm{~km}$ \\
\hline & $1 / 2 \mathrm{~d}$ & C3: $3550-3930$ & Mid-IR & $1.1 \mathrm{~km}$ \\
\hline & & $\mathrm{C} 4: 11.5-12.5 \mu$ & Thermal & $1.1 \mathrm{~km}$ \\
\hline LANDSAT/ & U.S.A. & MSS4: $500-600$ & Visible & $80 \mathrm{~m}$ \\
\hline \multirow[t]{3}{*}{ MSS } & (1972-) & MSS5: $600-700$ & Visible & $80 \mathrm{~m}$ \\
\hline & $16(18) \mathrm{d}$ & MSS6: $700-800$ & Near-IR & $80 \mathrm{~m}$ \\
\hline & & MSS7: $800-1100$ & Near-IR & $80 \mathrm{~m}$ \\
\hline LANDSAT/ & U. S.A. & TM1: $450-520$ & Visible & $30 \mathrm{~m}$ \\
\hline \multirow[t]{6}{*}{$\mathrm{TM}$} & (1984-) & TM2: $520-600$ & Visible & $30 \mathrm{~m}$ \\
\hline & $16 \mathrm{~d}$ & TM3: $630-690$ & Visible & $30 \mathrm{~m}$ \\
\hline & & TM4: $760-900$ & Near-IR & $30 \mathrm{~m}$ \\
\hline & & TM5:1550-1750 & Mid-IR & $30 \mathrm{~m}$ \\
\hline & & TM7:2080-2350 & Mid-IR & $30 \mathrm{~m}$ \\
\hline & & 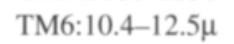 & Thermal & $120 \mathrm{~m}$ \\
\hline SPOT/ & France & B1: 500-590 & Visible & $20 \mathrm{~m}$ \\
\hline \multirow[t]{3}{*}{ HRV } & (1986-) & B2: $610-680$ & Visible & $20 \mathrm{~m}$ \\
\hline & $26 \mathrm{~d}$ & B3: 740-900 & Near-IR & $20 \mathrm{~m}$ \\
\hline & & B4: $510-730$ & Panchromatic & $10 \mathrm{~m}$ \\
\hline IRS-1A/ & India & B1: 450-520 & Visible & $72.5 \mathrm{~m}$ \\
\hline \multirow[t]{3}{*}{ LISS-I } & (1988-) & B2: $520-590$ & Visible & $72.5 \mathrm{~m}$ \\
\hline & $22 \mathrm{~d}$ & B3: $620-680$ & Visible & $72.5 \mathrm{~m}$ \\
\hline & & B4: $770-860$ & Near-IR & $72.5 \mathrm{~m}$ \\
\hline ERS-1/ & ESA & $\mathrm{C}: 5.3 \mathrm{GHz}$ & Microwave & $30 \mathrm{~m}$ \\
\hline \multirow[t]{2}{*}{ SAR } & (1991-) & & & \\
\hline & $35 \mathrm{~d}$ & & & \\
\hline JERS-1/ & Japan & B1: $520-600$ & Visible & $18 \mathrm{~m}$ \\
\hline \multirow[t]{2}{*}{ OPS } & (1992-) & B2: $630-690$ & Visible & $18 \mathrm{~m}$ \\
\hline & $44 \mathrm{~d}$ & B3: $760-860$ & Near-IR & $18 \mathrm{~m}$ \\
\hline SAR & & $\mathrm{L}: 1.275 \mathrm{GHz}$ & Microwave & $18 \mathrm{~m}$ \\
\hline
\end{tabular}

\section{Monitoring of crops and environment by earth observation satellites}

\section{Characteristics of satellite sensors and vegetation indices}

\section{Satellite sensors}

More than two decades have passed since LANDSAT-1 was launched by NASA in 1972. At present, several kinds of satellites are orbitting and observing the surface of the earth (Table 1). By the end of this century, still more, new satellites with special missions will be launched.

In the NOAA series, two satellites are maintained in polar orbit, one in a morning orbit and the other in an afternoon orbit. They provide a wide range of data, including sea surface temperature, cloud cover, data for land surface studies, temperature and humidity profiles, and ozone concentrations.

The LANDSAT and SPOT satellites provide high resolution imagery in the range of visible and infrared bands. They are used extensively for high resolution land surface studies.

The ERS series concentrates on global and regional environmental issues, making use of ac- 


\section{AGRICULTURAL AND FOOD SCIENCE IN FINLAND}

Vol. 5 (1996): 367-376.

tive microwave techniques, which enable a range of measurements to be made of the land, sea, and ice surface independent of cloud cover.

The aim of JERS-1 is to observe the earth using optical sensors and a high resolution synthetic aperture radar. Land surveys and monitoring of various resources are the main applications of this satellite.

\section{Spectral vegetation indices}

Based on the fact that green vegetation absorbs red $(\mathrm{R})$ wavelengths but reflects near-infrared (NIR) wavelengths, several spectral vegetation indices (VI) derived from satellite-borne data have been proposed. VI, including ratio vegetation index (RVI, NIR/R), difference vegetation index (DVI, NIR-R), normalized vegetation in$\operatorname{dex}(\mathrm{NDVI},(\mathrm{NIR}-\mathrm{R}) /(\mathrm{NIR}+\mathrm{R})$ ), are used the most by vegetation scientists. In addition, perpendicular vegetation index (PVI), soil adjusted vegetation index (SAVI), and K values have been proposed to eliminate background soil effects from vegetation.

\section{Crop monitoring from space}

In recent decades, many attempts have been made at extracting agro-environmental information at the regional level, and some useful technologies have been developed. As a result, the following information can be obtained by spaceborne sensors with high spectral/spatial resolutions, such as LANDSAT /TM and SPOT/HRV: 1) crop inventory and planting acreage estimates, 2) leaf area and phytomass estimates and yield prediction, 3) crop stress detection, and 4) agroenvironmental survey including soil, vegetation, water and atmosphere.

\section{Crop discrimination and planting acreage estimation}

From 1974 onwards, in the Large Area Crop Inventory Experiment (LACIE), jointly undertaken by NASA, NOAA and USDA, satellite remote sensing technology was applied, on an experimental basis, to forecast harvests in the major wheat producing areas of the world using LANDSAT/MSS data. As a result, a 1977 real-time forecast of the wheat production of the Soviet Union indicated that the system could operate and could be applied to other areas and other crops (MacDonald and Hall 1980). This project was followed by AgRISTARS, which focused on the assessment of crop conditions from space (AgRISTARS 1983). Many attempts at crop discrimination and planting acreage estimation have been made world-wide for a variety of crops using LANDSAT/MSS, LANDSAT /TM and SPOT/HRV data.

Recent studies and classification accuracies are summarized in Table 2. Most of the studies report accuracies exceeding $80 \%$. To illustrate, Table 3 shows crop discrimination results using LANDSAT/TM data in the Tokachi district of Japan. Here, the major crops were classified with 90\% accuracy (Fukuhara et al. 1988). In general, the accuracy of crop discrimination is strongly dependent on the spectral/spatial resolution of the satellite sensor, the timely acquisition of data at suitable crop stages, and ample field size for detection purposes.

\section{Biomass, leaf area and yield estimation}

Several spectral vegetation indices (VI) have been proposed to estimate vegetational information, including biomass, yield and leaf area. RVI, which employs the ratio between NIR and R, is often applied for the estimation of aboveground dry weight, fresh weight and leaf area.

Estimates of pasture grass yield at the first cut were made over Tochigi prefecture in central Japan, using LANDSAT/MSS data collected on May 22, 1979. The analysis was conducted by attempting first a land-use classification to identify pasture and meadows. Secondly, a multiple regression analysis was performed to estimate the yield of the first cutting in each pasture plot. To design the regression model, 26 plots with known yield data were prepared in advance. A high correlation was observed between the actual forage yield at the first cutting and the estimated yield based on LANDSAT/ MSS using the four bands (Akiyama et al. 1985). 
Akiyama, T. et.al.: Analysing agricultural ecosystems by remote sensing

Table 2. Results of crop discrimination studies using satellite data.

\begin{tabular}{|c|c|c|c|c|}
\hline $\begin{array}{l}\text { Country/ } \\
\text { District }\end{array}$ & $\begin{array}{l}\text { Satellite/ } \\
\text { Sensor }\end{array}$ & Main crops & Accuracy & Authors \\
\hline $\begin{array}{l}\text { U.S.A./ } \\
\text { Corn belt }\end{array}$ & $\begin{array}{l}\text { Landsat/ } \\
\text { MSS }\end{array}$ & Corn, Soybean & $83.9 \%$ & Batista et al. 1985 \\
\hline $\begin{array}{l}\text { U.S.A./ } \\
\text { Wisconsin }\end{array}$ & $\begin{array}{l}\text { Landsat/ } \\
\text { MSS }\end{array}$ & Alfalfa, Corn, Oats & $89.8 \%$ & Lo et al. 1986 \\
\hline Hungary & $\begin{array}{l}\text { Landsat/ } \\
\text { MSS }\end{array}$ & $\begin{array}{l}\text { Corn, Alfalfa } \\
\text { Sunflower etc. }\end{array}$ & $90 \%$ & Csillag 1986 \\
\hline $\begin{array}{l}\text { Argentine/ } \\
\text { Buenos Ires }\end{array}$ & $\begin{array}{l}\text { Landsat/ } \\
\text { MSSBTM }\end{array}$ & $\begin{array}{l}\text { Corn, Soybean } \\
\text { Sorgham etc. }\end{array}$ & $80 \%$ & Badhwar et al. 1987 \\
\hline $\begin{array}{l}\text { U.S.A./ } \\
\text { NY State }\end{array}$ & $\begin{array}{l}\text { Landsat/ } \\
\text { TM }\end{array}$ & $\begin{array}{l}3 \text { Vegetables } \\
4 \text { Crops }\end{array}$ & $\begin{array}{l}>90 \% \\
>75 \%\end{array}$ & Williams et al. 1987 \\
\hline $\begin{array}{l}\text { Japan/ } \\
\text { Tokachi }\end{array}$ & $\begin{array}{l}\text { Landsat/ } \\
\text { TM }\end{array}$ & 7 Crops & $90.1 \%$ & Fukuhara et al. 1988 \\
\hline $\begin{array}{l}\text { Hungary/ } \\
\text { Kiskore }\end{array}$ & $\begin{array}{l}\text { SPOT/XS } \\
\text { Landsat/TM }\end{array}$ & $\begin{array}{l}\text { Wheat, Soya } \\
\text { Alfalfa }\end{array}$ & $\begin{array}{l}\text { XS: } 85-88 \% \\
\text { TM: } 87-91 \%\end{array}$ & Büttner et al. 1989 \\
\hline $\begin{array}{l}\text { U.K./ } \\
\text { East Anglia }\end{array}$ & $\begin{array}{l}\text { SPOT/ } \\
\text { HRV }\end{array}$ & $\begin{array}{l}10 \text { Vegetation types } \\
4 \text { Vegetation types }\end{array}$ & $\begin{array}{l}71 \% \\
88 \%\end{array}$ & Jewell 1989 \\
\hline
\end{tabular}

Table 3. Results of crop classification studies using LANDSAT/TM data in Tokachi district, Japan (Fukuhara et al. 1988).

\begin{tabular}{llllllllll}
\hline & \multicolumn{1}{c}{ Performance $(\%)$} \\
Crop name & Su & Po & Ad & So & Co & Wh & Pa & Fo & Others \\
\hline Sugar beet (Su) & $\underline{96.3}$ & 0 & 0 & 0 & 0 & 0 & 1.7 & 0 & 2.0 \\
Potato (Po) & 0 & 98.5 & 0 & 0 & 0 & 0 & 0.5 & 0 & 1.0 \\
Adzuki bean(Ad) & 0 & 0 & $\underline{97.3}$ & 0.5 & 1.6 & 0 & 0 & 0 & 0.6 \\
Soybean (So) & 0 & 0 & 0 & $\underline{100.0}$ & 0 & 0 & 0 & 0 & 0 \\
Corn (Co) & 0 & 0 & 1.2 & 0 & $\underline{59.5}$ & 14.4 & 0 & 22.5 & 2.4 \\
Wheat (Wh) & 0 & 0 & 0 & 0 & 3.5 & 95.1 & 0 & 0.2 & 1.2 \\
Pasture (Pa) & 0 & 0 & 1.0 & 0 & 0 & 0 & $\underline{88.0}$ & 0 & 11.0 \\
Forest (Fo) & 0 & 0 & 1.0 & 0 & 6.1 & 0.6 & 0.5 & $\underline{90.2}$ & 1.6 \\
\hline
\end{tabular}

Underlined numbers indicate the proportion of crops correctly classified (\%).

Recent results of grain yield prediction for rice and wheat are presented in Table 4. A high accuracy was attained with a multiple regression model using 2 or $3 \mathrm{TM}$ bands for rice. Meteorological damage caused by cold wind and flooding are also analysed effectively using satellite data. For example, rice damage caused by flooding was highly correlated with the turbidity of water (Yamagata and Akiyama 1988), which reflected in TM bands 2 and 3 .

\section{Crop stress detection}

Plants experience various kinds of stresses during growth, including stresses caused by atmospheric factors, by rhizospheric factors, or biotic stresses caused by a variety of organisms. Moreover, in recent years, it has often been reported that toxic materials in the environment resulting from human activities can inflict damage on crops and forests, as in the case of acid rain. If farmers could detect various crop stresses in the 
Vol. 5 (1996): 367-376.

Table 4. Results of crop yield prediction using satellite data.

\begin{tabular}{|c|c|c|c|c|c|c|}
\hline Crops & $\begin{array}{l}\text { Country/ } \\
\text { district }\end{array}$ & $\begin{array}{l}\text { Satellite/ } \\
\text { sensor }\end{array}$ & $\begin{array}{l}\text { Date of data } \\
\text { acquisition }\end{array}$ & Model used & $\begin{array}{l}\text { Correlation, } \\
\text { Standard deviation }\end{array}$ & Authors \\
\hline \multirow[t]{2}{*}{ Rice } & Thailand/ & LANDSAT/ & 09/Dec/88 & MRM (TM 1, 5, 7) & \multirow[t]{2}{*}{$\mathrm{R}^{2}=0.85$ to 0.92} & \multirow[t]{2}{*}{ Tennakoon et al. 1992} \\
\hline & Saraburi & TM & 27/Dec/88 & Growth model & & \\
\hline Rice & India/ & IRS-1A/ & $12,13 / \mathrm{Oct} /$ & Area Weighted & $\mathrm{SD} ;-2 \%$ to $+14 \%$ & Patel et al. 1991 \\
\hline Rice & $\begin{array}{l}\text { Orissa } \\
\text { Japan/ } \\
\text { Ishikari }\end{array}$ & $\begin{array}{l}\text { LISS-1 } \\
\text { LANDSAT/ } \\
\text { TM }\end{array}$ & $\begin{array}{l}88 \\
23 / \text { Sep/86 }\end{array}$ & $\begin{array}{l}\text { Average Ratio } \\
\text { MRM (TM2,3,4, } 5 \\
\text { \& TM4/TM3) }\end{array}$ & $\mathrm{R}^{2}=0.953$ & Mubekti et al. 1991 \\
\hline \multicolumn{2}{|c|}{ Cold wind } & & & & & \\
\hline & $\begin{array}{l}\text { J Japan/ } \\
\text { Ishikari }\end{array}$ & $\begin{array}{l}\text { LANDSAT/ } \\
\text { MSS }\end{array}$ & 19/Sep/80 & MRM (MSS5, 6) & $\mathrm{R}=0.91$ & Miyama et al. 1983 \\
\hline $\begin{array}{l}\text { Flood } \\
\text { damaged } \\
\text { rice }\end{array}$ & $\begin{array}{l}\text { Japan/ } \\
\text { Ibaraki }\end{array}$ & $\begin{array}{l}\text { LANDSAT/ } \\
\text { TM }\end{array}$ & 6/Aug/86 & MRM (TM2, 3) & $R=0.972$ & Yamagata and Akiyama 1988 \\
\hline Wheat & $\begin{array}{l}\text { Brazil/ } \\
\text { Sao Paolo }\end{array}$ & $\begin{array}{l}\text { LANDSAT/ } \\
\text { TM }\end{array}$ & $\begin{array}{l}24 / J u n / 86 \\
27 / J u n / 87\end{array}$ & $\begin{array}{l}\text { Meteo. model } \\
\text { TM4/TM3 }\end{array}$ & $R^{2}=0.65$ & Rudorff and Batista 1991 \\
\hline Wheat & $\begin{array}{l}\text { Japan/ } \\
\text { Ishikari }\end{array}$ & $\begin{array}{l}\text { LANDSAT/ } \\
\text { TM }\end{array}$ & $\begin{array}{l}\text { 27/Jun/86 } \\
\text { 29/May/90 }\end{array}$ & MRM (TM2, 3) & $\mathrm{R}^{2}=0.66$ to 0.79 & Shiga 1993 \\
\hline Wheat & $\begin{array}{l}\text { India/ } \\
\text { Sultanpur }\end{array}$ & $\begin{array}{l}\text { LANDSAT } \\
\text { TM }\end{array}$ & $22 / \mathrm{Feb} / 86$ & $\begin{array}{l}\text { NDVI, RVI } \\
\text { Layers method }\end{array}$ & $\begin{array}{l}\text { Variance } \\
0.1958\end{array}$ & Singh et al. 1992 \\
\hline Wheat & $\begin{array}{l}\text { India/ } \\
\text { Haryana }\end{array}$ & $\begin{array}{l}\text { LANDSAT/ } \\
\text { TM } \\
\text { IRS/1A/ } \\
\text { LISS-1 }\end{array}$ & $\begin{array}{l}26 / \mathrm{Jan} / 89 \\
\text { to } \\
18 / \mathrm{Feb} / 89\end{array}$ & $\begin{array}{l}\text { Linear yield-spectral } \\
\text { index }\end{array}$ & $\begin{array}{l}\text { Deviation }+14 \% \\
\text { to }-18 \%\end{array}$ & Sharma et al. 1993 \\
\hline
\end{tabular}

MRM: Multiple Regression Model

$\mathrm{R}$ : Multiple regression coefficient

$\mathrm{R}^{2}$ : Coefficient of determination

SD: Standard deviation

early stages of an infection or a nutrient deficiency before any symptoms appear, a timely intervention could prevent the damage to the yield and save the quality of the final product.

Water deficit in plants can be clearly detected by NIR and mid-infrared (MIR) wavelength reflectances, which indicate the thermal changes caused by stomatal movement. The same band can be used for the crop stress caused by soilborne diseases, as it enables to detect the wilting of the leaves (Torigoe 1992).

Stresses due to meteorological factors do not always show up early. Spikelet sterility is often caused by low temperatures during the flowering stage of rice in the northern part of Japan. Usually, the fertile ears die off at ripening, while the sterile ears remain green at harvest time. Using LANDSAT /MSS imagery, Mi- yama et al. (1983) were able to create a map of the cold damage to rice on the Ishikari plane of northen Japan.

\section{Agro-environmental monitoring}

\section{Soil survey}

Many scientists have classified soil types using satellite data. Information on organic matter and moisture content in the soil is particularly important for farmers. Fukuhara et al. (1980) were able to determine differences in the moisture contents of the soil using LANDSAT/MSS data in the Tokachi district in Japan. In the same area, Hatanaka et al.(1989) classified the organic matter content in the soil, using band 3 reflectance data from LANDSAT/TM obtained in 


\section{AGRICULTURAL AND FOOD SCIENCE IN FINLAND}

Akiyama, T. et.al.: Analysing agricultural ecosystems by remote sensing

May, when the surface of the upland field was almost bare. The classification results were plotted on a 1/50,000 scale map, and used by officers of the agricultural extension services.

\section{Land evaluation}

It is possible for the developing countries to select the land suitable for agricultural development using satellite data. These data can provide several thematic maps relating biomass, soil moisture and present landuse. When these thematic maps are overlaid on existing meshed topographic or geographic maps, we can obtain value-added information on the productivity of the land (Akiyama et al. 1987).

In recent years, the need to quantify the function of agricultural land has become increasingly important in Japan. Attempts have been made to quantify the multiple functions of such land, for example the impact of the cultivation of paddy rice on soil conservation, landscape maintenance or the capacity for water purification. Remote sensing by a satellite is a prominent tool for such evaluations.

\section{Arctic Science Project with Finland}

\section{International Cooperative Study on Observation of Variabilities in the Arctic Atmosphere, Hydrosphere and Biosphere, and their Interactions}

One of our most serious concerns today is the fact that global environment change (chiefly deterioration) is taking place at an unprecedented speed, because of ever-growing human activity. We have come to realize that polar regions are very important areas for understanding processes of global change; no less so than the tropical and mid-latitude areas, where most of the human race live.

The ongoing environmental changes are not only global in scale, but also varied, and involve diverse and complicated processes, calling for an interdisciplinary approach to address the issue. In this context, in 1990 the Science and Technology Agency of Japan organized a 5-year program "International Cooperative Study on Observation of Variabilities in the Arctic Atmosphere, Hydrosphere and Biosphere, and their Interactions" in cooperation with 15 governmental institutes, laboratories and universities.

The Arctic Science Project consists of three sections, namely, 1) Arctic oceanography and glaciology, 2) Atmospheric chemistry, 3) Arctic vegetation and agricultural environment. The Arctic vegetation team enrolled the assistance of the Technical Research Centre of Finland (VTT), Turku University and the Agricultural Research Centre of Finland. Here, we report on two topics investigated by the vegetation monitoring sub-teams in the Arctic Science Project.

\section{Vegetation change monitoring in the boreal area}

This part of the project was conducted by scientists in the Forestry and Forest Products Research Institute of Japan working together with VTT of Finland. An outline of the collaborative research is given below.

The study concentrated on the monitoring of vegetation change using satellite data. Seasonal and successional changes of spectra, as a basis for long term monitoring, were studied over the southern boreal forest zone using LANDSAT/ TM images (Awaya et al. 1995).

Two monitoring methods were compared at a test site in Kevo, at the northern tip of Finland. The first was boundary detection using Laplacian filtering, and the second biomass change detection by subtraction between two normalized difference vegetation indices (NDVI) of LANDSAT/MSS images acquired in 1972 and 1987. A zonal shift of arctic vegetation was not captured using these methods, but damage to birch forests by the moth caterpillar were clearly detected. This phenomenon appeared to 


\section{AGRICULTURAL AND FOOD SCIENCE IN FINLAND}

Vol. 5 (1996): 367-376.
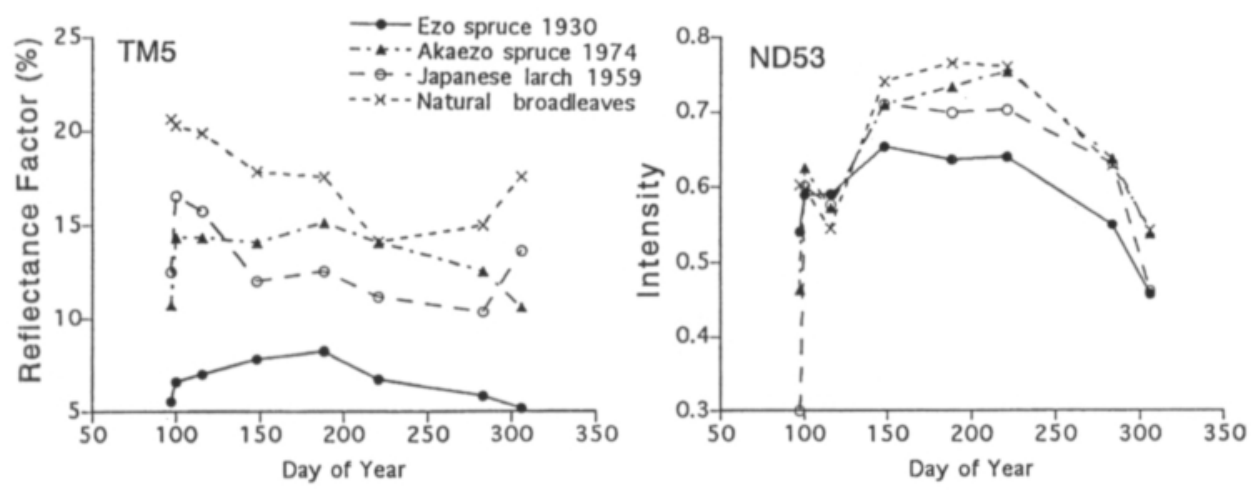

Fig.1 Seasonal changes of spectra for different the tree species estimated using TM data (Awaya et al. 1995). The spectral changes, from early spring to late autumn, were drawn using eight TM images taken between 1985 and 1993. The numbers in the figure caption represent the year of planting of the trees.

be caused by a combination of the moth caterpillar and by temperatures lower than the average in the latter half of the 1960's. It suggested that the vegetation changes are occurring that are related both ecological processes, i.e. the damage and the recovery of the trees, and the effects of global climate change.

The seasonal spectral patterns of the southern boreal forests were clearly identified in the TM3, TM4 and TM5 of LANDSAT in Hokkaido, Japan. Though the spectra of the young spruce stands seemed to be affected by mixed broadleaved trees in TM3 and TM4, seasonal spectral patterns could be classified into two types, evergreen and deciduous trees, in TM5 (Fig.1, left). Forest types classified according to the major tree showed constant intensities in a normalized difference ratio of TM5 and TM3 (ND53) over the growing season (Fig.1, right). The successional spectral patterns of the spruce stands varied between seasons and channels. However, the relationship between the digital number and the stand age was expressed using an exponential function (not shown here).

\section{Spectral properties of subarctic ground vegetation}

This experiment was conducted by the National
Institute of Agro-Environmental Sciences, and the National Grassland Research Institute of Japan collaborating with VTT of Finland and Turku University (Shibayama et al. 1995).

Ground truth information for remote sensing, to assess the phenology of boreal plants, is needed in global scale climate change research activities. A boom-mounted, four-band spectroradiometer was installed to measure seasonal radiances in the green $(520-600 \mathrm{~nm})$, red $(630$ $690 \mathrm{~nm})$, near-infrared (765-900nm) and midinfrared (1570-1730nm) spectral bands from boreal shrub canopies over the growing season in northernmost Finland at Utsjoki. It measured the spectra of four fixed ground plots, each one once per hour, from early June to mid-September between 0600 and 1800 hrs local time. A reflectance panel was also measured a few minutes before and after measurement of each plot. The plant phenology on each plot was also observed weekly during the experiment. Seasonal reflectance factors for each plot in each band were calculated based on a new calibration method. It involves a correction for the degradation of the reference panel. A hand-held spectroradiometer was also used to measure the plant canopies and the reference panel in the early autumn. The turning point dates of the seasonal near-infrared $(765-900 \mathrm{~nm})$ and red $(630-690 \mathrm{~nm})$ reflectance factors might indicate the end of 


\section{AGRICULTURAL AND FOOD SCIENCE IN FINLAND}

Akiyama, T. et.al.: Analysing agricultural ecosystems by remote sensing

Plot\#1
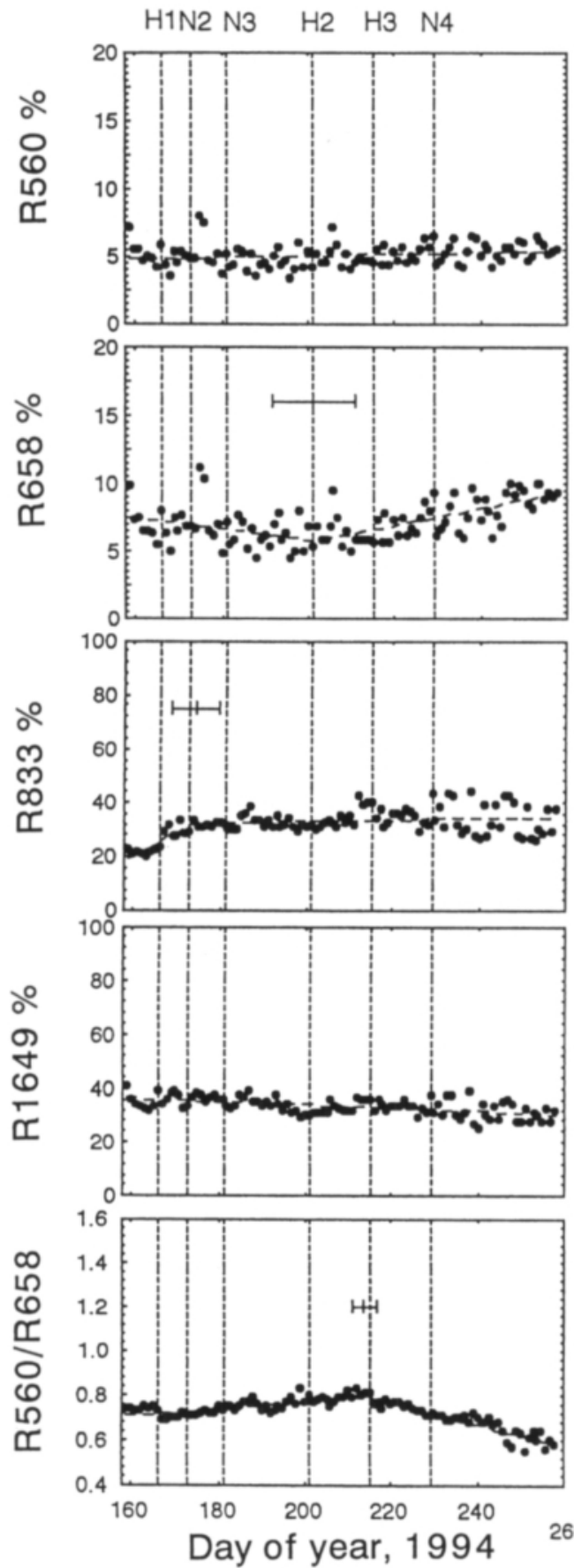

Plot\#2
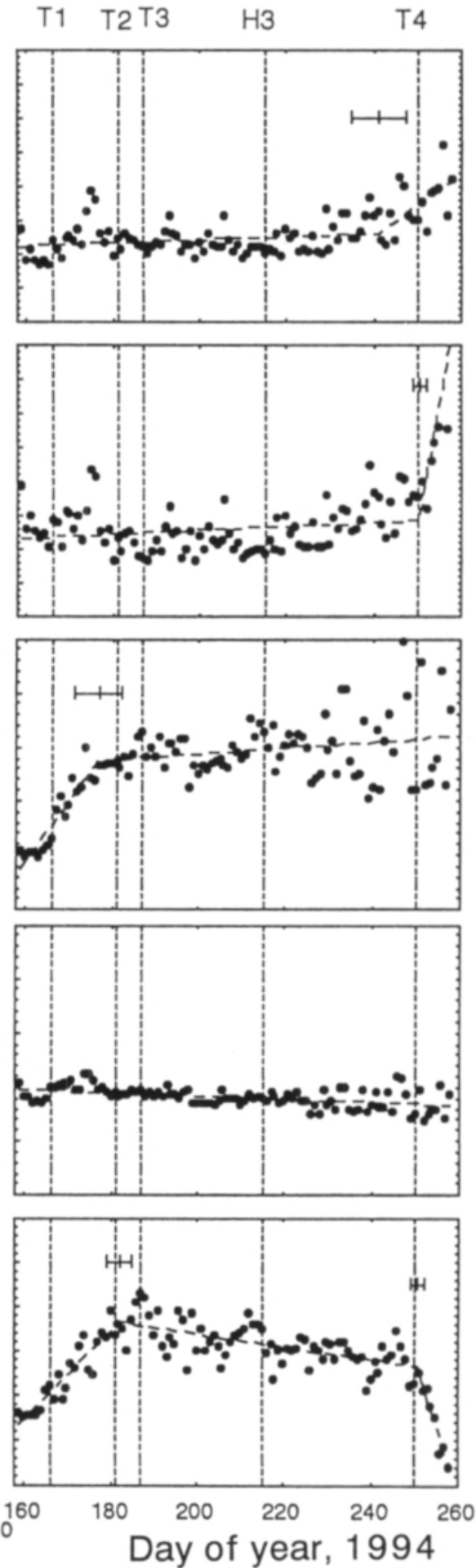

Fig. 2. Seasonal patterns of daily reflectance factors at bands $560,658,833$ and $1649 \mathrm{~nm}$, and the bi-band ratio of the 560 and $658 \mathrm{~nm}$ reflectance factors measured for the plant plots (Plots\#1,\#2) by the automated four-band spectroradiometer at Kevo. The lateral bars show the $95 \%$ confidence intervals of the estimated intersection points (the turning point dates of the radiometric variables) (Shibayama et al. 1995). 


\section{AGRICULTURAL AND FOOD SCIENCE IN FINLAND}

Vol. 5 (1996): 367-376.

growth and the beginning of the autumnal tints, respectively. The ratio of the green (520-600nm) and red band reflectance factors, however, seemed to be more accurate in predicting these turning points (Fig.2).
Acknowledgements. We wish to express our gratitude to Dr.T. Häme, Dr. A. Salli and Dr. A. Lohi of the Technical Research Centre of Finland and Dr. M. Alanen and Dr. S. Neuvonen of the Kevo Subarctic Research Institute, University of Turku, for their diligent support in the Arctic Science Project. The authors are also deeply grateful to Professor T. Mela for his helpful suggestions.

\section{References}

AgRISTARS Program Management Group 1983. Agriculture and resources inventory surveys through aerospace remote sensing. Research Report, Fiscal Year 1982, APJ2-0393. p. 1-45.

Akiyama, T., Miyama, K., Soemarman, H. \& Setiyono, J. 1987. Land evaluation system using Landsat data for agricultural development. Application of PATTERN method in North Sumatera. Journal of the Japanese Agricultural Systems Society 3(2): 74-89.

-, Yasuda, Y., Emori, Y. \& Miyama, K. 1985. Grassland diagnosis by remote sensing techniques. 2. First cutting yield estimate of pasture using Landsat multispectral data. The Journal of Japanese Society of Grassland Science 31: 97-103. (in Japanese)

Awaya, Y., Tanaka, N., Häme, T. \& Lohi, A. 1995. Vegetational change monitoring in the boreal area using remote sensing. Changes in the northern Finland and spectral characteristics of spruce. Proceedings of International Arctic Science Symposium, Tsukuba, D: 30-61.

Badhwar G.D., Gargantini, C.E. \& Redondo, F.V. 1987. Landsat classification of Argentina summer crops. Remote Sensing of Environment 7: 265-281.

Batista, G.T., Hixson, M.M. \& Bauer, M.E. 1985. LANDSAT MSS crop classification performance as a function of scene characteristics. International Journal of Remote Sensing 6: 1521-1533.

Büttner, G. \& Csillag, F. 1989. Comparative study of crop and soil mapping using multitemporal and multispectral SPOT and Landsat Thematic Mapper data. Remote Sensing of Environment 29: 241-249.

Csillag, F. 1986. Comparison of some classification methods on a test-site. International Journal of Remote Sensing 7: 1705-1715.

Fukuhara, M., Amano, T. \& Miyaji, N. 1988. Creation of cropping map using Landsat TM data. Proceedings of 1988 Annual Meeting of the Japan Society of Photogrammetry and Remote Sensing, J-2: 169-172. (in Japanese) -, Hayashi, S. Yasuda, Y. Emori. Y. \& lisaka, J. 1980. Soil moisture analysis for soil mapping. Proceedings of the Machine Processing of Remotely Sensed Data Symposium, Purdue University, Indiana, U.S.A. p. 1-10.

Hatanaka, T., Shiozaki, H., Fukuhara, M., Miyaji, N. \& Saito, G. 1989. Estimation of organic matter contents of upland soils with Landsat TM data. Japanese Journal of Soil Science and Plant Nutrition 69: 426-431. (in Japanese)
Jewell, N. 1989. An evaluation of multi-date SPOT data for agriculture and land use mapping in the United Kingdom. International Journal of Remote Sensing 10: 939951.

Lo, T.H.C., Scarpace, F.L. \& Lillesand, T.M. 1986. Use of multitemporal spectral profiles in agricultural land-cover classification. Photogrammetric Engineering and Remote Sensing 52: 535-544.

MacDonald, R.B. \& Hall, F.G. 1980. Global crop forecasting. Science 208: 670-679.

Miyama, K. Sato, H. Yasuda, Y. \& Emori, Y. 1983. An applied study on a remote sensing techniques to survey agricultural land. Survey technique for geographical distribution of damage to rice from cold weather using Landsat MSS data. Transactions of JSIDRE 105: 27-35. (in Japanese)

Mubekti, Miyama, K. \& Ogawa, S. 1991. Study on rice yield distribution by using Landsat TM data. The Hokkaido National Agricultural Experiment Station, Rural Development Research 5: 101-113.

Patel, N.K., Ravi, N., Navalgund, R.R., Dash, R.N., Das, K.C. \& Patnaik, S. 1991. Estimation of rice yield using IRS-1A digital data in coastal tract of Orissa. International Journal of Remote Sensing 12: 2259-2266.

Rudorff, B.F.T. \& Batista, G.T. 1991. Wheat yield estimation at the farm level using TM Landsat and agrometeorological data. International Journal of Remote Sensing 12: 2477-2484.

Sharma, T., Sudha, K.S. Ravi, N., Navalgund, R.R., Tomar, K.P. Chakravarty, N.V.K. \& Das, D.K. 1993. Procedures for wheat yield prediction using Landsat MSS and IRS-1A data. Intrernational Journal of Remote Sensing 14: 2509-2518.

Shibayama, M., Salli, A., Hame, T., Iso-livari, L., Morinaga, S., Inoue, Y. \& Akiyama, T. 1995. Spectral properties of subarctic ground vegetation during the growth period. -Preliminary results of a 1994 experiment in the northernmost Finland. Proceedings of the International Arctic Science Symposium, Tsukuba, Japan, D: 629.

Shiga, H. 1993. Agricultural information system in Hokkaido: Integration of arable land information and application of remote sensing for land evaluation. Journal of the Japanese Agricultural Systems Society 9: 32-39. (in Japanese)

Singh, R., Goyal, R.C., Saha, S.K. \& Chhikara, R.S. 


\title{
AGRICULTURAL AND FOOD SCIENCE IN FINLAND
}

Akiyama, T. et.al.: Analysing agricultural ecosystems by remote sensing

1992. Use of satellite spectral data in crop yield estimation surveys. International Journal of Remote Sensing 13: 2583-2592.

Tennakoon, S.B., Murty, V.V.N. \& Eiumnoh, A. 1992. Estimation of cropped area and grain yield of rice using remote sensing data. International Journal of Remote Sensing 13: 427-439.

Torigoe, Y. 1992. Low input sustainable agriculture and information system: Developing integrated pest manage- ment for soilborne disease. Journal of the Japanese Agricultural Systems Society 8: 149-157. (in Japanese) Williams, V.L., Philipson, W.R. \& Philpot, W.D. 1987. Identifying vegetable crops with Landsat Thematic Mapper data. Photogrammetric Engineering and Remote Sensing 53: 187-191.

Yamagata, Y. \& Akiyama, T. 1988. Flood damage analysis using multi-temporal Landsat Thematic Mapper data. International Journal of Remote Sensing 9: 503-514.

\section{SELOSTUS}

\section{Maatalousekosysteemien analysointi ja sadon ennustaminen kaukokartoituksen avulla}

\author{
Tsuyoshi Akiyama, Y. Inoue, M.Shibayama, Y. Awaya ja N. Tanaka \\ National Institute of Agro-Environmental Sciences, National Grassland Research Institute ja Forestry and Forest \\ Products Research Institute, Japani
}

Tämän artikkelin alussa arvioidaan muutamia satelliittikaukokartoituksen uusimpia sovelluksia maataloudessa ja lopussa esitellään japanilais-suomalainen yhteistyöhanke Arctic Science Project. LANDSAT/ TM-satelliittikuva-aineistoa voidaan käyttää maataloustuotannon seurannassa, sillä kuvien spektri/spatiaalinen tarkkuus on hyvä. Erittely- ja kartoitustekniikat ovat kehittyneet niin paljon, että viljalajit voidaan erottaa toisistaan $80 \%$ tarkkuudella. Satelliittiaineiston avulla on arvioitu sadon biomassaa, esimerkiksi lehtialaa sekä kuiva- ja tuorepainoa, ja en- nustettu viljasatoa erilaisia laajaspektrisiä kasvillisuusindeksejä käyttäen. Myös ravinteiden ja veden puutteen aiheuttamaa stressiä on onnistuttu analysoimaan. Arctic Science Projectissa seurattiin boreaalisia metsäalueita LANDSAT-satelliittiaineiston avulla. Subarktisen pohjakasvillisuuden spektriominaisuuksiin perustuvia fenologisia muutoksia mitattiin nelikanavaisella spektroradiometrillä. Käännekohdat vuodenaikaisissa lähes-infrapuna- ja punaheijastumissa saattavat osoittaa kasvun päättymistä ja ruskan alkua. 